\title{
A IGREJA COMO MÃE SUFICIENTEMENTE BOA À LUZ DOS CONCEITOS DE WINNICOTT
}

\author{
THE CATHOLIC CHURCH AS A GOOD-ENOUGH MOTHER \\ BASED ON WINNICOTT'S CONCEPTS
}

Deborah Meireles Costa Guimarães ${ }^{(*)}$

\begin{abstract}
RESUMO
Este artigo identifica a Igreja - comunidade autêntica de fé - como Mãe suficientemente boa à luz dos conceitos de Winnicott. Seu objetivo é analisar como a Igreja Católica tem se revelado uma mãe suficientemente boa através dos seus ensinamentos sociais, a partir da conceituação winnicotiana de mãe suficientemente boa, ambiente favorável e integração. Afirma-se que a importância dos cuidados retratados na teoria de Winnicott e também nos documentos da Igreja Católica explicitam a preocupação com o desenvolvimento integral do ser humano em todas as suas dimensões. Confirma-se também a relevância da teoria winnicotiana e da Doutrina Social da Igreja no que diz respeito às conquistas e aos cuidados com o ser humano, sob a clareza de que uma falha ou ausência de uma mãe suficientemente boa, interferirá no desenvolvimento saudável do indivíduo.
\end{abstract}

PALAVRAS-CHAVE: Igreja. Doutrina social. Mãe Suficientemente Boa. Maternagem.

\begin{abstract}
A study was performed on the Catholic Church - authentic community of faith - as a goodenough mother, based on Winnicott's concepts. The study aimed at analyzing how the Catholic Church has been proving to be agood-enough mother by means of its social teachings, based on the Winnicottian concept of a good-enough mother, a favorable environment and also integration. Results show that the importance of the care as portraited in the Winnicott's theory, as well as in the Catholic Church documents, the concern about the whole development of the human being in all its dimensions were also disclosed. Also confirmed was the relevance of both the Winnicottian theory and the Church's Social Doctrine in relation to the achievements of and the care towards the human being, under the clear thought that either the failure or the absence of a good-enough mother will definitely interfere in the healthy development of the subject.

KEYWORDS: Church. Social Doctrine. Good-enough Mother.
\end{abstract}

\footnotetext{
(*) Professora titular e Psicóloga do Centro Universitário de Sete Lagoas-UNIFEMM - MG, Brasil. Mestre em Ciências da Religião pela Pontifícia Universidade Católica de Minas Gerais - PUC Minas, Brasil. E-mail: deborahmcguimaraes@gmail.com
} 


\section{INTRODUÇÃO}

Diante de tantos questionamentos ligados à Igreja Católica, o que me motivou a tornar real este artigo foi o desejo de me aprofundar na maneira como esta Igreja se situa no mundo como mãe e mestra, atenta às necessidades da humanidade. Este trabalho foi norteado por uma pesquisa teórico-analítica da Doutrina Social da Igreja cotejando com as obras de Winnicott no que se refere à conceituação de mãe suficientemente boa situando-se na linha de pesquisa Razão, Religião e Contemporaneidade, do Programa de Pós-Graduação em Ciências da Religião da PUC Minas. Trata-se apenas de uma aproximação, sem confundir os campos epistemológicos da teologia com a psicologia. A ideia de uma leitura "à luz de" pretende preservar o devido distanciamento.

Os erros históricos da Igreja no percurso da história da humanidade, onde se fez contratestemunho dos ensinamentos de Jesus Cristo, não invalidam a proposta de autêntica comunidade de fé. Desse modo, toda vez que nos referirmos ou empregarmos o termo Igreja, o horizonte que se abre é aquele de uma autêntica comunidade, enquanto categoria teológica original, e não como Igreja histórica ou constituição hierárquica. Em outros termos: falamos da Igreja em seu sentido original e enquanto meta, ou mesmo como Utopia do Reino.

Portanto, o caminho que se trilhou foi o de buscar, não os erros históricos da Igreja ,mas em que manifestações essa Igreja vai se revelando como mãe atenta e amorosa junto ao processo de desenvolvimento integral de seus filhos.

A pergunta que norteou esse artigo foi: Como a Igreja Católica no percurso da história da humanidade tem se manifestado como "mãe suficientemente boa", enquanto comunidade autêntica. Para responder a essa pergunta busquei articular a teoria do amadurecimento humano do pediatra e psicanalista Winnicott, que retrata a importância da "mãe suficientemente boa" no processo de integração do indivíduo, com a Doutrina Social da Igreja Católica. Assim, nosso tema se descortina como: A Igreja como Mãe suficientemente boa à luz dos conceitos de Winnicott.

A trajetória percorrida por este trabalho se inicia primeiramente quando busco apresentar alguns conceitos fundamentais da Teoria do Amadurecimento Humano de Winnicott, de modo a que se possa entender o que significa, no processo de desenvolvimento do indivíduo, uma "mãe suficientemente boa". Em seguida, busco nos documentos da Doutrina Social da Igreja Católica, 
identificar quais são as suas propostas que fazem com que ela venha a se tornar uma Igreja Mãe e Mestra.

Finalizando, apresento a perspectiva da Maternagem: Igreja como mãe suficientemente boa através de ações desenvolvidas em diversos setores da Igreja, fundamentadas na doutrina social, à luz dos conceitos winnicottianos.

\section{TEORIA DO AMADURECIMENTO}

Winnicott, inglês, cristão anglicano, pediatra, formulou a teoria do amadurecimento humano com base nas concepções de que todo indivíduo humano é dotado de uma tendência inata ao amadurecimento. Winnicott acreditava no potencial criativo humano, e que o ser humano já traz em si as potencialidades do viver; recusa assim o naturalismo e o determinismo, isto é, recusa a objetivação do ser humano. As bases para a saúde mental do indivíduo, segundo este autor, são estabelecidas nos estágios iniciais de desenvolvimento e são produto dos processos de amadurecimento e das condições ambientais. ${ }^{1}$

A teoria do amadurecimento humano de Winnicott está fundamentada em dois grandes pilares: a tendência inata ao amadurecimento e a existência contínua de um ambiente facilitador. Essa tendência inata só se desenvolverá se houver ambiente facilitador.

Para Winnicott o processo de amadurecimento inicia-se após a concepção e prossegue ao longo da vida do indivíduo até sua morte natural, significando o último acontecimento a ser integrado. $\mathrm{O}$ caminho percorrido vai desde os estágios primitivos de dependência absoluta para o estágio de dependência relativa, até chegar aos estágios de independência relativa.

$\mathrm{O}$ amadurecimento não se dá de forma linear, sendo que um estágio precisa ter sido razoavelmente alcançado para que o outro possa ser experimentado de forma efetiva.

Segundo Dias, o amadurecimento pode ser assim descrito:

Numa apreensão global, o amadurecimento pode ser descrito como uma jornada (journey) que parte da dependência absoluta passa por um periodo de dependência relativa, chega às etapas que estão no rumo da independência, até chegar à independência

\footnotetext{
${ }^{1}$ Winnicott formulou uma teoria do amadurecimento pessoal normal, considerada por ele mesmo como a "espinha dorsal" (backbone) do seu trabalho teórico e clínico. A ênfase dessa teoria recai sobre os estágios iniciais, pois é nesse período que estão sendo constituídas as bases da personalidade e da saúde psíquica. (DIAS, 2003, p.13).
} 
relativa, que é o estado em que o individuo saudável se mantém regularmente ao longo da vida. (DIAS, 2003, p.98).

Para cada estágio há tarefas e conquistas a serem integradas, que derivam da própria integração.

De acordo com Dias $(2003)^{2}$ o uso do termo integração é utilizado para indicar a tendência inata ao amadurecimento, mas também para designar as várias integrações parciais que vão acontecendo ao longo do processo de desenvolvimento.

Segundo Winnicott, todo bebê possui uma tendência herdada e um potencial para a existência, para o crescimento e para alcançar a maturidade. Porém, para que o amadurecimento aconteça é necessário que haja um ambiente facilitador. É esse ambiente inicial que vai propiciar a capacidade para experiência.

O primeiro ambiente para o bebê é a sua mãe, tanto a sua pessoa quanto as condições ambientais e emocionais que ela cria para o bebê.

$\mathrm{O}$ crescimento de cada criança vai depender do ambiente que a circunda. Para Winnicott, o ambiente é facilitador quando oferece condições para o crescimento do indivíduo em direção à saúde e, se o ambiente falha, numa proporção superior às possibilidades de o indivíduo suportar, pode ser gerada uma instabilidade que propicie o adoecer. Assim, ele retrata:

O desenvolvimento emocional ocorre na criança se provêm condiçôes suficientemente boas, vindo o impulso, para o desenvolvimento de dentro da própria criança. As forças no sentido da vida, da integração da personalidade e da independência são tremendamente fortes e, com condições suficientemente boas, a criança progride: quando as condições não são suficientemente boas essas forças ficam contidas dentro da criança e, de uma forma ou de outra, tendem a destrui-la. (WINNICOTT, 1982 p. 63).

O que caracteriza a dependência absoluta é o fato de o bebê depender inteiramente da mãe para ser e para realizar sua tendência inata à integração.. Encontrando condições satisfatórias, mãe e lactante se tornam, por um período, um só.

\footnotetext{
${ }^{2}$ Dias é estudiosa da obra de Winnicott e membro da Sociedade Brasileira de Psicanálise winnicottiana, autora do livro "A Teoria do Amadurecimento de D. W. Winnicott", cujo objetivo é apresentar, de maneira unitária e organizada, os principais elementos conceituais da teoria do amadurecimento, explicitando seus pressupostos e descrevendo os estágios do processo, com suas respectivas tarefas e conquistas.
} 
Portanto, no início, o ser só é possível com outro ser humano. Durante esta fase, a continuidade do ser é a experiência que resulta dos cuidados contínuos e devotados da mãe suficientemente boa ao seu bebê, que a princípio ainda é misturado a ela. Nessa fase é muito importante para a mãe, sentir-se amada pelo pai da criança, pois, para poder desempenhar satisfatoriamente suas funções, ela precisa do amparo do pai e da sociedade. Nesse momento, a mãe também se encontra em estado de dependência com o eu bebê.

As mulheres que acabam de ter os seus bebês encontram-se, elas mesmas, necessariamente, em estado de dependência. É possivel dizer até que as mães são tão desamparadas em relação ao desamparo do bebê quanto ele próprio. Para desempenhar bem a sua tarefa, ela necessita sentir-se amada na sua relação com o pai da criança, e aceita nos circulos familiares, assim como nos mais amplos que constituem a sociedade. O papel do pai,neste momento, é de extrema importância,sobretudo na função de proteção da mãe e provedor do lar. (DIAS, 2003, p.138-139).

Durante esta fase a continuidade do ser é o sentimento que resulta da fusão mãe, suficientemente boa com o bebê. A mãe suficientemente boa é a "mãe devotada comum", é aquela que proporciona à criança ser o seio e vai ao encontro do gesto espontâneo do bebê, fornecendo a ilusão de onipotência infantil. Essa mãe suficientemente boa é descrita por Winnicott como aquela que sustentava seu bebê, concebendo-o como outro ser. Assim ele retrata, a respeito deste termo:

Este termo é utilizado na descrição da dependência que pertence à primeirissima infäncia. A implicação é que a sanide mental tem de se fundar, em todos os casos, na mãe, que, na saide, atende às necessidades que o seu bebê tem de minuto a minuto. O que o bebê precisa, e necessita de modo absoluto, não é algum tipo de perfeição de maternagem, mas uma adaptação suficientemente boa, aquela que faz parte de uma velação viva em que a mãe temporariamente se identifica com o seu bebê. (WINNICOTT, 1994, p. 37).

De acordo com Winnicott, o papel da mãe é o de oferecer o holding (segurar) e o handling (manejar), apresentando o mundo ao seu bebê. É através do holding feito pela mãe, no qual ela se identifica com as necessidades do seu bebê, que se torna possível a passagem do estado de não integração - que é uma característica do recém-nascido - para a integração posterior.

Oferecer o holding e o handling para a humanidade é o que a Igreja - na sua especificidade, que é diferente da teoria psicológica de Winnicott - propicia através das Encíclicas Sociais, pois as mesmas têm como objetivo lutar pela dignidade humana em sua totalidade, a fim de que o ser humano possa viven- 
ciar o processo de integração constante. Julgamos que esta é uma aproximação possível, sem violar o campo epistemológico da psicanálise. Ou ainda: é nossa proposta de leitura à luz da teoria de Winnicott.

Conforme Winnicott, três tarefas esperam o indivíduo na vida adulta. A primeira tarefa é a de continuar amadurecendo e manter-se vivo. O amadurecimento é contínuo e só se finda com a morte. Para isso é necessário usarmos a nossa criatividade, a nossa capacidade de enfrentar cada passagem ou acontecimento do nosso viver. Alcançar a integração de forma plena e saudável é ser capaz de manter contato com a objetividade do mundo ao seu redor, sem perder a dimensão do seu mundo interno.

A segunda tarefa consiste na aceitação da impotência e da imperfeição. Esta tarefa nos leva ao encontro das nossas imperfeições e do mundo que nos circunda.

E a terceira é a de poder envelhecer e morrer. Segundo Dias assim Winnicott nos esclarece:

Se eu tiver uma vida razoavelmente longa, espero encolher e tornar-me suficientemente pequeno para passar pelo estreito buraco da morte (1984g, p. 225). Mas aprender a morrer só é possível para alguém que viveu e teve experiências. E só é possivel ter vivido e permanecer vivo tendo alcançado o estado unitário que permite dizer EU SOU. Apenas a partir desta condição é possível tanto viver como morrer. Não há morte, diz Winnicott, exceto considerando-se uma totalidade (1984h p. 48). (DIAS, 2003, p. 296).

Winnicott considera, pois, que a morte só existe se considerarmos a vida uma totalidade, ou seja, quando houver uma plena integração pessoal. De acordo com a teoria winnicottiana assim é o percurso do amadurecimento humano. A Igreja também tem uma trajetória cuja proposta é o desenvolvimento integral do ser humano. É com a trajetória das encíclicas que se compõe o corpo da doutrina social da Igreja Católica. Ei-las: Rerum Novarum, sobre os problemas do capital do trabalho; Quadragésimo Anno, sobre a construção da ordem social; Mater et Magistra, sobre o cristianismo e o progresso social; Populorum Progressio sobre o desenvolvimento dos povos; Laboren Exercens, sobre o trabalho humano; Sollicitudo Rei Socialis, sobre a preocupação social da Igreja; Centesimus Annus, sobre várias questões da doutrina social. Nestas é que se encontram os fundamentos oferecidos por essa Mãe suficientemente boa, disponibilizadas para que as pessoas, mediante eles, possam atingir sua independência relativa. 


\section{ENSINAMENTO SOCIAL COMO EXPRESSÃO DOS CUIDADOS DA IGREJA-MÃE}

Sabemos que, em nossos dias, estamos passando por uma crise nos campos econômico, social e político, que tem afetado o equilíbrio vital do ser humano. Pode-se perceber que a concentração de renda pertence a poucos e grande parcela de nossa população vive em condições miseráveis, excluídas do mínimo necessário para se viver dignamente.

Nunca o gênero humano teve ao seu dispor tão grande abundância de riquezas, possibilidades e poderio econômico; $e$, no entanto, uma imensa parte dos habitantes da Terra é atormentada pela fome e pela miséria, e inúmeros são ainda analfabetos. (PAULO VI, 1965, GS, 4).

Nesse novo momento da história o desafio é conviver com esse intenso grau de mudanças, com as alterações provocadas no mundo e o impacto que todo esse processo exerce na vida e nas relaçóes.

Predomina-se a cultura do excesso, do individualismo, do consumismo, do descartável, da fluidez, e a pessoa vai se sentindo desorientada, perdendo muitas vezes os seus referenciais.

Cabe à Igreja anunciar os princípios morais e denunciar tudo aquilo que impede a vivência dos direitos fundamentais da pessoa humana. Na Constituição pastoral Gaudium et Spes, a Igreja retrata a sua íntima união com toda a família humana. Ela se sente ligada ao "gênero humano e à sua história". (PAulo VI, 1965, GS, 1) proferindo o seguinte pronunciamento:

A humanidade vive hoje uma fase nova da sua história, na qual profundas e rápidas transformaçôes se estendem progressivamente a toda a terra. Provocadas pela inteligência e actividade criadora do homem, elas reincidem sobre o mesmo homem, sobre os seus juizos e desejos individuais e colectivos, sobre os seus modos de pensar e agir, tanto em relação às coisas como às pessoas. De tal modo que podemos já falar duma verdadeira transformação social e cultural, que se reflecte também na vida religiosa. (PAULO VI, 1965, GS, 4).

Outra manifestação da Igreja em relação ao bem estar da humanidade, se encontra nos dizeres da Exortação Apostólica Evangeli Nuntiandi, onde Ela, solicita à humanidade, não aceitar a violência como caminho para a libertação; e propõe o seguinte: 
Nós regozijamo-nos de que a Igreja tome uma consciência cada dia mais viva do modo próprio, genuinamente evangélico, que ela tem para colaborar na libertação dos homens... Ela procura suscitar cada vez mais nos ânimos de numerosos cristãos a generosidade para se dedicarem à libertação dos outros. Ela dá a estes cristãos "libertadores" uma inspiração de fé e uma motivação de amor fraterno, uma doutrina social a que o verdadeiro cristão não pode deixar de estar atento, mas que deve tomar como base da própria prudência e própria experiência, a fim de a traduzir concretamente em categorias de ação, de participação e de compromisso (PAULO VI, 1975, EM, 38).

Nesse exercício de ensinar e aplicar a moral cristã, a Igreja vai se construindo como mãe e mestra e necessita do devotamento dos pastores, da ciência, dos teólogos, da contribuição de todos os cristãos e de todos os homens de boa vontade.

O desejo do lucro exagerado agride também a Natureza, provocando um desequilíbrio ecológico comprometedor.

[...] Um dos grandes desafios de nosso tempo relaciona-se à consciência planetária; como encontrar um caminho civilizacional que saiba incluir a todos, incluindo a natureza; um caminho que possibilite o enriquecimento da compreensão do bumano que envolve não apenas a relação consigo mesmo e com os outros, mas igualmente a relação com o cosmos, que é o seu lugar natal. [...] (TEIXEIRA, 2009, p. 211).

Diante dos desafios sócio-econômicos e políticos, a Doutrina Social da Igreja busca captar à luz da fé, as dimensões éticas e as responsabilidades morais com a humanidade.

Designa-se como Doutrina Social da Igreja (DSI) o conjunto de escritos e mensagens, cartas encíclicas, exortações, pronunciamentos, declarações, que compõem o pensamento do magistério católico a respeito da chamada "questão social". A Igreja se preocupa com homens e mulheres em concreto, na medida em que cada qual está incluído no mistério da Redenção onde Cristo se uniu a cada um para sempre.

A humanidade torna-se o itinerário principal que a Igreja deve percorrer ao cumprir a sua missão de Mãe e Mestra.

Hoje, a doutrina social da Igreja centra-se, sobretudo nos homens e nas mulheres enquanto estão envolvidos numa complexa rede de relacionamentos, dentro das sociedades modernas.

Enquanto aproveita todos os contributos das ciências e da filosofia, a sua doutrina social dirige-se para o auxilio da humanidade na sua caminhada de salvação. (JOÃo PAULO II, 1991, CA, 53-54). 
Responsável pelo desenvolvimento pleno e integral do ser humano, a Igreja acompanha os acontecimentos da história, ciente da interpelação recíproca entre Evangelho e vida social, entre fé e vida.

A primeira e mais fundamental raiz de tudo o que a Igreja pode dizer a respeito do homem e da sociedade é a Palavra revelada de Deus, como experiência histórica de um povo que se sentiu chamado à Aliança. Deus falou pelos profetas, porém, chegada a plenitude dos tempos, falou-nos por seu próprio Filho. (BIGGO; ÁVILA, 1981, p. 82-83).

Toda a contribuição do cristianismo para a compreensão da condição humana está contida dentro da pessoa de Jesus, Deus feito homem. Deus se revelou aos homens em forma humana se tornando homem. Por isso quem vê a Jesus vê a Deus, e o cristão vê a Jesus no seu próximo.

[...] Jesus revela ao homem o mistério do próprio homem, chamado a ser filho de Deus e a participar da vida divina. Como Cristo nos ensinou, é esta vida divina, da qual participamos que fundamenta a verdadeira fraternidade de todos, filhos do Pai comum.Quando a Igreja anuncia aos povos a fraternidade humana, a fonte uiltima de sua palavra encontra-se no próprio desígnio de Deus. (BIGGO; ÁVILA, 1981, p. 82-83).

A Igreja não se restringe à teoria. Ela a aplica. Através dos preceitos divinos, convida a humanidade a vivenciar seus respectivos deveres como amar a Deus e ao próximo.

O homem descobre na fé uma insuspeitada capacidade de superar-se a si mesmo, de amar a Deus como Pai e de falar a Ele como filho, em nome de Jesus Cristo e por inspiração do Espirito Santo. É capaz de amar em Cristo, a todos os homens, inaugurando na história a radical novidade do Evangelho: amar e perdoar até aos que nos perseguem. (Mt 5,46-47). (BIGGO; ÁVILA, 1981, p. 82-83).

Outra preocupação manifestada pela Igreja é de que não haja o domínio de um ser humano por outro, reafirmando o conceito do homem como imagem de Deus.

[...] A dignidade da pessoa humana, um conceito novo de liberdade como entrega ao outro na reciprocidade, um ideal de comunhão e de participação, estão implícitos nesse conceito do homem, como ser criado à imagem de Deus, e irmãos em Cristo. Podemos afirmar que cada homem tem mais valor que todo universo material, e que todos os homens têm o mesmo valor sem discriminação. (BIGGO; ÁVILA, 1981, p. 82-83).

Desde a Encíclica Rerum Novarum, de Leão XIII, o Magistério da Igreja que aborda as questôes sociais, coloca a pessoa humana e sua dignidade fundamental no centro do seu ensinamento social e a "questão social" como linha de ação. 
Criada à imagem e semelhança de Deus, a pessoa humana deve viver sua liberdade diante de Deus e da sua consciência, saboreando dos seus direitos inalienáveis e respondendo por seus deveres.

O ensino social da Igreja enfatiza "a centralidade do homem dentro da sociedade", enquanto "ser social", constituindo-se no "primeiro caminho que a Igreja deve percorrer na realização de sua missão.". Este ser humano é essencialmente chamado a coexistir, vivendo com os outros em sociedade. Ele necessita dos outros e juntos crescem e se aperfeiçoam. A relação com o próximo passa a ser estruturante da vida humana, bem como pertence à essência da vida cristã. (AgOstini, 2002, p. 11).

Os princípios da DSI são um convite da Igreja a ser aceito por todos aqueles que acreditam na solidariedade humana, na qual cada um se coloca empenhando os seus valores na promoção dos outros. A Igreja Católica, à Luz do Evangelho de Jesus Cristo, dispõe uma visão muito clara das necessidades do mundo e dos problemas enfrentados pela humanidade. Em meio às contradições da sociedade, a Igreja busca estar radicalmente comprometida com o fortalecimento da pessoa humana. A Igreja não aceita a violência, o terrorismo, as práticas antievangélicas, e vê o homem como o autor, o centro e o fím de toda a vida econômica e social. Assim ela se manifesta:

Uma sociedade justa só pode ser realizada no respeito pela dignidade transcendente da pessoa humana. Esta representa o fim último da sociedade, que a ela é ordenada: Portanto, a ordem social e o seu progresso devem ordenar-se incessantemente ao bem das pessoas, pois a organização das coisas deve subordinar-se à ordem das pessoas e não ao contrário. (IGREJA CATÓLICA, 2009, p. 83).

É na perspectiva desse olhar para o ser humano em sua totalidade, preocupando-se com o bem comum, procurando ensinar as atitudes justas na relação com os bens terrenos e nas relações sócio-econômicas, que a Igreja tem se pronunciado sobre a questão social.

Nessa trajetória da DSI pode-se observar que a Igreja Católica procura ser uma Mãe Solícita, sempre atenta às necessidades espirituais e materiais de seus filhos, principalmente daqueles marginalizados pela sociedade.

De acordo com o Evangelho de Nosso Senhor Jesus Cristo, desde o Papa Leão XIII até o Papa Bento XVI,

A doutrina social, "por si mesma, tem o valor de um instrumento de evangelização" e se desenvolve no encontro sempre renovado entre a mensagem evangélica e a história humana. Assim entendida, tal doutrina é via peculiar para o exercicio do ministério da Palavra e da função profética da Igreja: "para a Igreja, ensinar e difundir a dou- 
trina social pertence à sua missão evangelizadora e faz parte essencial da mensagem cristã, porque essa doutrina propõe as suas conseqüiências diretas na vida da sociedade e enquadra o trabalho diário e as lutas pela justiça no testemunho de Cristo Salvador.” (IGREJA CATÓLICA, 2009, p. 48).

Todos buscam orientar os povos no sentido de promoverem uma sociedade mais justa e mais fraterna. Este sentimento se faz presente na Introdução do Compêndio da Doutrina Social da Igreja.

A Igreja, sinal na história do amor de Deus para com os homens e da vocação de todo o gênero bumano à unidade na filiação do único Pai, também com este documento sobre a sua doutrina social quer propor a todos os homens um humanismo à altura do designio de amor de Deus sobre a história, um humanismo integral e solidário, capaz de animar uma nova ordem social, econômica e politica, fundada na dignidade e na liberdade de toda a pessoa humana, a se realizar na paz, na justiça e na solidariedade. (IGREJA CATÓLICA, 2009, 24).

Buscar o estudo da DSI é recriar, para os dias atuais, a dimensão sócio política da Boa Nova de Jesus.

No artigo "Doutrina Social da Igreja História e desafios", o Pe. Alfredo J. Gonçalves nos oferece a seguinte reflexão:

Um rápido olhar sobre dois textos biblicos pode nos dar uma idéia do que significa retornar o estudo da DSI.

O primeiro é do evangelista Lucas: Jesus encontra-se recolbido num lugar à parte e, sob a insistência dos discípulos, ensina o Pai nosso... (Lc, 1-4)

No segundo texto, o evangelista Mateus faz um breve resumo das atividades de Jesus. (Mt 9,35-38)

No primeiro caso, Jesus está na montanha em oração: no segundo, Jesus percorre as cidades e aldeias, "compadecendo-se das multidóes "cansadas e abatidas." (GONÇALVES, 2011).

Assim é a Igreja como Mãe, principalmente à luz dos ensinamentos do Concílio Vaticano II e da DSI como um todo orgânico; na busca de compreender a totalidade dos elementos que compõem a vida do homem e da mulher, propicia cuidados que possam tornar o ser humano mais fraterno, criativo e atuante no processo de construção de uma sociedade mais justa. Desse modo os desafios modernos - como "falhas ambientais" - simbolizam o chão existencial concreto diante do qual a Igreja deve ser uma Mãe suficientemente boa para seus filhos.

A Gaudium et Spes é um documento inspirado que retrata a Igreja como mãe, pois representa uma nova forma de relacionamento da Igreja com 
o mundo, voltando-se para valores humanos e temporais e se organizando em torno de questões relacionadas ao trinômio homem-sociedade-história.

Esse documento aprofunda a questão das desigualdades geradas pelo desenvolvimento econômico e afirma que a eliminação de tais desigualdades só se pode basear numa reta compreensão de desenvolvimento, devendo ser presidido pelo homem sem nenhuma exclusão. Assim, orienta a Mãe Igreja:

[...] a finalidade da produção não é o mero aumento dos produtos, nem o lucro ou o poderio, mas o serviço do homem: do homem integral, isto é, tendo em conta a ordem das suas necessidades materiais e as exigências da sua vida intelectual, moral, espiritual e religiosa, de qualquer homem ou grupo de homens, de qualquer raça ou região do mundo. A actividade econômica, regulando-se pelos métodos e leis próprias, deve, portanto, exercer-se dentro dos limites da ordem moral, para que assim se cumpra o desígnio de Deus sobre o homem. (PAULO VI, 1965, GS, 64).

Ao se preocupar com os homens e as mulheres desde as suas necessidades básicas mais primitivas até alcançar a transcendência, a Igreja demonstra exercer a maternagem. Como mãe, a Igreja se preocupa com todo homem e com o homem todo. A maternagem não tem como suporte a condição biológica, mas está amparada no afeto e no profundo desejo de cuidar. Aliás, o cuidado se revela como a condição pré-ontológica do ser-mãe da Igreja. Portanto, maternagem é escolha. É uma decisão de cuidar, amar, proteger, doar.

Por outro lado, a Igreja, quando oferece o Holding, ou seja, quando clama a todos os segmentos sociais por condições básicas para o ser humano viver suas experiências no cotidiano da vida, ela está exercendo a função da maternagem. Aqui se confirma apenas que somos em comunhão uns com os outros e com nosso entorno social.

Por fim, quando a Igreja grita pelos menos favorecidos, no momento em que eles não têm voz nem vez no contexto social, Ela está cumprindo o papel de mãe suficientemente boa.

A Igreja, através de seus cuidados junto à humanidade de todos os tempos - humana que também é - se faz presente pré-ontologicamente em sua missão.

Várias são as passagens bíblicas em que podemos identificar o cuidado de Deus para cada um de nós. O Profeta Isaías nos mostra o quanto Deus se preocupa com os seus filhos quando diz: "pode uma mulher esquecer-se tanto do filho que cria, que não se compadeça dele, do filho do seu ventre? Mas, ainda que esta se esqueça, eu, todavia eu não me esquecerei de ti” (Isaías, 49,15). 
Muitos outros textos, incontáveis passagens bíblicas, demonstram a essencialidade da missão da Igreja e os cuidados de Deus para com o povo. No Novo Testamento, é a figura do próprio filho de Deus encarnado. Este horizonte do cuidado de Deus para com o povo é o protótipo da relação mãe-filho.

"Agrada-te do Senhor, e ele satisfará os desejos do teu coração. Entrega o teu caminho ao Senhor; confia nele, e o mais ele fará” (Salmo 37, 4-5). Através dessa passagem pode se refletir a importância da confiança na relação filho-Deus. Este o protótipo da relação filho-mãe. Há uma entrega porque se sabe que o cuidado vai acontecer. Semelhante ideia se encontra na passagem que diz: "Descansa no Senhor, e espera nele" (Salmo 37, 4-5-7). Nos momentos de desânimo, de desencanto, descansar no colo da mãe é encontrar força para dar continuidade ao caminhar.

Todas essas passagens bíblicas vêm confirmar a vocação da Igreja como guardiã do seu povo.

Uma mãe amorosa exerce a misericórdia em todos momentos em que seus filhos necessitam. Independentemente da idade, raça, cultura. Assim a Dives in Misericordia testemunha a perspectiva da misericórdia.

O Antigo Testamento proclama a misericórdia do Senhor mediante numerosos termos com significados afins. Estes termos são diferenciados no seu conteúdo particular, mas tendem a convergir, se assim se pode dizer, de vários pontos de vista para um único conteúdo fundamental, a fim de exprimir a riqueza transcendental da misericórdia e, ao mesmo tempo, para aproximá-la do homem sob aspectos diversos. (JOÃo PAULO II, 1980, DM, 4).

No mistério da criação, o amor do Pai também se faz presente em todo contexto da história da humanidade. E é nesse contexto revelado tanto na Antiga como na da Nova Aliança que a Igreja, através dos seus cuidados, vai confirmando seu papel de mãe, herdado por um processo histórico que se faz presente desde o Antigo Testamento. Enfim, a Igreja como mãe suficientemente boa tem que contar, e de fato sempre conta, com a figura paterna, Jesus, seu fundador (Efésios)

O mistério da criação está em conexão com o mistério da eleição, que de modo especial plasmou a história do povo cujo pai espiritual é Abraão, como mérito da sua fé. Por meio deste povo que caminha através da história, tanto da Antiga como da Nova Aliança, aquele mistério de eleição refere-se a todos e a cada um dos homens e a toda a grande familia bumana... Cristo revela o Pai na mesma perspectiva, na perspectiva $e$ no estado dos espiritos já preparados, como o demonstram numerosas páginas do Antigo Testamento. Como remate desta revelação, na véspera da sua morte diz ao Apóstolo 
Filipe aquelas memoráveis palavras: "Há tanto tempo que estou convosco e não me conheces?... Quem me vê, vê o Paì. (Jỗo PAULO II, 1980, DM, 4).

Demonstrando mais uma prova de cuidado com a humanidade, Deus envia o seu filho Jesus que, no cotidiano da sua vida vai se revelando amorosamente em suas atitudes.

A Igreja como mãe suficientemente boa traduz em ação, em gestos concretos, seu compromisso de viver junto à humanidade o que Jesus deixou como ensinamento.

Os gestos e palavras de Jesus são expressões de solidariedade e de cuidado que se encontram nos evangelhos.

O aspecto mais universal e eficaz do humanismo do Evangelho é dado pelo preceito do amor, enquanto centro e epilogo de toda a mensagem cristã. Depois de ter oferecido em si um exemplo de vida, toda ela inspirada no amor ao próximo, Cristo, pela primeira vez na história, proclamou que toda a lei se resume em dois preceitos, que, aliás, se integram num só: o amor a Deus e o amor ao próximo. (NoGARE, 1982, p. 47).

Todas as passagens bíblicas desde o Antigo Testamento até o Novo Testamento vêm nos propor um estilo de vida voltado para o respeito, a solidariedade e o compromisso com o desenvolvimento integral do ser humano. Enfatizando a importância da não desintegração do ser humano é que a Igreja vai se revelando mãe que cuida, através do seu testemunho histórico manifestado em sua doutrina social, como também em várias pastorais e campanhas que buscam a conscientização de toda a sociedade, a fim de que esta se empenhe em possibilitar uma vida digna a todo ser humano.

Toda essa caminhada da Igreja vem demonstrar que ela não se restringe à teoria. Ela se faz presente através de vários movimentos e pastorais. A Conferência Nacional dos Bispos do Brasil - CNBB, conta com o Setor de Pastoral Social que se faz presença e serviço na sociedade. Numa postura de Mãe suficientemente boa que cuida, que se preocupa com o processo de integração, oferecendo um ambiente favorável é que a Igreja torna-se viva no meio do povo. Dentre as várias pastorais existentes, sobressaem a pastoral da criança, do menor, da sobriedade e da saúde, todas como referência de uma IgrejaMÃE amorosa e pressurosa com seus filhos. 


\section{EPÍLOGO}

Neste artigo, procurou-se evidenciar a suma importância dos cuidados retratados na teoria de Winnicott, bem como nos documentos da Igreja Católica, ambos explicitando sua preocupação com o desenvolvimento integral do ser humano em qualquer de suas dimensões. Este trabalho confirmou a relevância da teoria winnicotiana e da Doutrina Social da Igreja no que diz respeito às conquistas e aos cuidados com o ser humano, deixando claro que a falha ou ausência de uma mãe suficientemente boa, sem dúvida, interferirá no desenvolvimento saudável do indivíduo.

Winnicott, em sua teoria do desenvolvimento, reafirma a todo o momento a importância de uma mãe suficientemente boa, aquela que, num ambiente favorável, vai tornando possível o processo de integração do indivíduo. Em sua teoria, ele explicita que as mães são imprescindíveis no início da vida de seus bebês, pois são elas que trazem a capacidade de proteger e permitir a continuidade de ser do bebê. De igual forma é a preocupação do Magistério da Igreja pela centralidade e a dignidade da pessoa humana, preocupação esta revelada nos documentos que compõem a doutrina social.

A pessoa humana criada por Deus, à sua imagem e semelhança nem sempre tem ocupado o lugar conferido por sua dignidade - de ser humano. Haja vista o número relevante de pessoas em nosso planeta que é vítima da injustiça, da marginalização, do desrespeito aos seus direitos mais fundamentais.

A Doutrina Social da Igreja é solidária com o ser humano e preocupa-se com a vida humana na sociedade, denunciando, em todas as esferas, as injustiças que afetam a dignidade humana. Há uma solicitação implícita nas entrelinhas recorrendo ao empenho social de cada cristão, uma vez que, desde a criação, o ser humano apresenta uma dignidade apta a ser cuidada e promovida.

Esse cuidado e promoção se potencializam através das várias pastorais e movimentos existentes no seio da Igreja, à luz da doutrina social. Através das vertentes do anúncio e da denúncia, a Igreja vai cuidando das necessidades da humanidade, atenta aos anseios manifestados em cada contexto histórico, político e cultural.

Através ainda desses cuidados manifestados em todos os documentos que compõem a doutrina da Igreja, é que afirmo que a mesma pode ser chamada de mãe suficientemente boa. 
Portanto, não é uma atitude ingênua identificá-la como mãe suficientemente boa, pois, à luz dos ensinamentos do Mistério da Encarnação, ELA se manifesta através de atitudes de entrega amorosa a seus filhos testemunhando assim o oposto dos erros históricos cometidos no percurso da história da humanidade. Novamente reprisamos aqui o entendimento da Igreja enquanto comunidade autêntica.

Por fim, faz-se oportuno destacar que a grande maioria das pessoas que frequentam a Igreja Católica, não conhecem as riquezas e as exigências contidas nos documentos sociais da Igreja, nos quais se proclama a todos os homens e mulheres de boa vontade que invistam na construção de uma sociedade mais justa e fraterna; o ideal seria que todos os conhecessem.

\section{REFERENNCIAS}

AGOSTINI, Nilo. A doutrina social da Igreja e problemas de nosso tempo. In: AGOSTINI, Nilo. Ética cristã e desafios atuais. Petrópolis: Vozes, 2002.

BIGGO, Pierre; ÁVILA, Fernando B. Fé cristã e compromisso social. São Paulo: Paulinas, 1981 .

DIAS, Elza. A teoria do amadurecimento humano de D. W. Winnicott. Rio de Janeiro: Imago, 2003.

GONÇALVES, Alfredo J. Doutrina social da Igreja história e desafios. Brasília: CEFEP. Disponível em: <http://www.cefep.org.br/documentos/textoseartigos/politica evangelhodsi/Doutrina\%20Social\%20da\%20Igraja\%20Historia\%20e\%20desafios.doc/view >. Acesso em: dez. 2011.

IGREJA CATÓLICA. Catecismo da Igreja Católica. 2. ed. Petrópolis: Vozes, 1993.

IGREJA CATÓLICA. Conselho Pontifício Justiça e Paz. Compêndio da doutrina social da Igreja. São Paulo: Paulinas, 2009.

JOÃO PAULO II, Papa. Carta encíclica Centesimus Annus do Sumo Pontífice João Paulo II: aos veneráveis irmãos no episcopado ao clero as famílias religiosas, aos fiéis da Igreja Católica e a todos os homens de boa vontade no centenário. 2. ed. São Paulo: Paulinas, 1991.

JOÃO PAUlO II, Papa. Carta encíclica Redemptoris missio do Sumo Pontifice João Paulo II sobre a validade permanente do mandato missionário. Cidade do Vaticano: Libreria Editrice Vaticana, 1990.

JOÃO PAULO II, Papa. Dives in Misericodia sobre a misericórdia divina. Roma: Vaticano,1980. Disponível em: < http://www.vatican.va/edocs/POR0066/_INDEX. HTM>. Acesso em: dez. 2011. 
NOGARE, Pedro Dalle. Humanismos e anti-humanismos. Petrópolis: Vozes, 1982.

PAULO VI, Papa. Constituição Pastoral Gaudium et Spes sobre a Igreja no mundo atual. Roma: Vaticano,1965. Disponível em: < http://www.vatican.va/archive/ hist_councils/ii_vatican_council/documents/vat-ii_const_19651207_gaudium-et-spes_ po.html >. Acesso em: dez. 2011.

PAULO VI, Papa. Exortação apostólica Evangelii nuntiandi: ao episcopado, ao clero, aos fiéis de toda a Igreja sobre a evangelização no mundo contemporâneo. São Paulo: Edições Paulinas, 1975.

TEIXEIRA, Faustino. O sentido místico da consciência planetária In: OLIVEIRA, Pedro A. Ribeiro de; SOUZA, José Carlos Aguiar de (Org.). Consciência planetária e religião: desafios para o século XXI. São Paulo: Paulinas, 2009.

WINNICOTT, D. W. Explorações psicanaliticas. Porto Alegre: Artmed,1994.

WINNICOTT, D. W. A criança e seu mundo. Rio de Janeiro: Zahar, 1982.

Recebido em 06/02/2013

Aprovado em 31/05/2013 